\title{
Brain-Derived Neurotropic Factor Deficiency
}

National Cancer Institute

\section{Source}

National Cancer Institute. Brain-Derived Neurotropic Factor Deficiency. NCI Thesaurus.

Code C120385.

Presumed deficiency of brain-derived neurotropic factor (BDNF), associated with loss-offunction mutation(s) in the BDNF gene. 